\title{
BALLAST WATER: A POLYPHASIC APPROACH IN THE EVALUATION OF POTENTIAL PHYTOPLANKTONIC BIOINVASION
}

\section{Água de lastro: uma abordagem polifásica na avaliação da bioinvasão potencial fitoplancônica}

\author{
Ellen DellAgnolo ${ }^{1}$, Márcio da Silva Tamanaha², Charrid Resgalla Junior ${ }^{3}$ \\ ${ }^{1}$ Oceanógrafa, mestra em Ciência e Tecnologia Ambiental, bolsista do programa de pesquisa da Capes. \\ E-mail: ellen.dellagnolo@gmail.com \\ ${ }^{2}$ Coordenador do Laboratório de Ficologia, professor na Universidade do Vale do Itajaí, Centro de Ciências \\ Tecnológicas da Terra e do Mar (CTTMar), Itajaí, SC, Brasil. E-mail: mt@univali.br \\ ${ }^{3}$ Coordenador do Laboratório de Ecotoxicologia Marinha, professor na Universidade do Vale do Itajaí, Centro de \\ Ciências Tecnológicas da Terra e do Mar (CTTMar), Itajaí, SC, Brasil. E-mail: cresgalla@univali.br
}

\begin{abstract}
The main transport vector for exotic-invasive species around the world is ballast water in merchant ships, crossing natural biogeographic barriers. This is one of the main factors responsible for the reduction and homogenization of the global biota. As phytoplankton is the main group transported by these vessels, this study assesses the risk of bioinvasion in the port complex of Itajaí and Navegantes (southern Brazil), using a polyphasic approach, mixing classical taxonomy with molecular biology. Ballast water collections were carried out to analyze the traditional taxonomy and for clonal cultivation in the laboratory. A successful cultivation of 12 local strains and 10-ballast water was successful. In the latter case, some fresh water, contrary to the statement by the commanders of the exchange of water in the deep ocean (> $200 \mathrm{~m}$ ). Molecular identification was performed by sequencing the complete ITS region, confirming the presence of Thalassiosira minuscula Krasske, 1941, harmful and of public health interest, previously not mentioned for the region. The species Pleurosigma W. Smith, 1852; Asterionellopsis glacialis (Castracane) Round, 1990; Trieres mobiliensis (Bailey) Ashworth and E.C. Theriot, 2013; Thalassiosira minima Gaarder, 1951; Skeletonema pseudocostatum Medlin, 1991; Pectinodesmus holtmannii E. Hegewald, C. Bock and Krienitz, 2013; Neodesmus Hindák, 1976; and Pseudopediastrum boryanum (Turpin) E. Hegewald, 2005, were identified. The results indicate the possibility of growth of the species found in the ballast environment, which may negatively alter the disposal environment.
\end{abstract}

Keywords: exotic species, molecular identification, marine phytoplankton, port complex of Itajaí and Navegantes.

Recebido em: 06/11/2019

Aprovado em: 13/04/2021

Publicado on-line em: 20/12/2021 


\section{RESUMO}

O principal vetor de transporte de espécies exótico-invasoras pelo mundo é a água de lastro em navios mercantes, transpondo barreiras biogeográficas naturais. Esse é um dos principais fatores responsáveis pela redução e homogeneização da biota global. Como o fitoplâncton é o principal grupo transportado por essas embarcações, este estudo avalia o risco de bioinvasão no complexo portuário de Itajaí e Navegantes (sul do Brasil) por abordagem polifásica, mesclando a taxonomia clássica com a biologia molecular. Foram realizadas coletas de água de lastro para análise da taxonomia tradicional e para o cultivo clonal em laboratório. Efetivou-se um sucesso de cultivo de 12 cepas locais e 10 de água de lastro. Nesse último caso, algumas de água doce, contrariando a declaração dos comandantes da realização da troca de água em oceano profundo (> $200 \mathrm{~m}$ ). A identificação molecular foi realizada pelo sequenciamento da região ITS completa, confirmando a presença de Thalassiosira minuscula Krasske, 1941, nociva e de interesse de saúde pública, anteriormente não mencionada para a região. Identificaram-se as espécies Pleurosigma W. Smith, 1852; Asterionellopsis glacialis (Castracane) Round, 1990; Trieres mobiliensis (Bailey) Ashworth e E.C. Theriot, 2013; Thalassiosira minima Gaarder, 1951; Skeletonema pseudocostatum Medlin 1991; Pectinodesmus holtmannii E. Hegewald, C. Bock e Krienitz 2013; Neodesmus Hindák, 1976; e Pseudopediastrum boryanum (Turpin) E. Hegewald, 2005. Os resultados indicam a possibilidade de crescimento de espécies encontradas no ambiente lastro, podendo alterar negativamente o ambiente de descarte.

Palavras-chave: espécies exóticas, identificação molecular, fitoplâncton marinho, complexo portuário de Itajaí e Navegantes.

\section{INTRODUCTION}

The navigation of merchant ships in oceanic waters around the world has directly influenced the global biota and its homogenization, and ballast water can be considered the main vector for the transport of exotic and invasive species (Wittenberg \& Cock, 2001). Although indispensable for the operational safety of the ships, ballast water can transport a large quantity of marine species, and has the potential to cause ecological damage, economic losses and even harm to public health (Antaq, 2016; Neves \& Barbosa, 2010; Wittenberg \& Cock, 2001). These potentially invasive organisms include bacteria, microalgae, eggs, cysts and larvae of different species.

In an attempt to manage this problem, the IMO (International Maritime Organization) has given some guidelines, such as exchanging ballast water in deep sea, to ensure that species of coastal regions do not survive in oceanic waters, where the physical and chemical variables of the environment are very different (Souza, 2010). One of the organisms most commonly found in ballast water is phytoplankton (Souza, 2010) that, due to its survival capacity and ability to form cysts of resistance, can present the potential to cross natural biogeographical barriers (Lopes et al., 2009; Souza, 2010).

During the 19th century, Ostenfeld raised the possibility of bioinvasion by ballast water to explain the appearance of the diatom Trieres mobiliensis ((Bailey) Ashworth \& Theriot), (= Odontella sinensis (Bailey) in the North Sea in 1903 (Bolch \& Salas, 2007). Streftaris, Zenetos and Papathanassiou (2005) listed 53 non-native phytoplankton species 
between the Arctic, Baltic, North Atlantic, Mediterranean and Black seas, with 25 dinoflagellates and 15 diatoms. In Brazil, in the last list made available by the Ministry of the Environment, researchers identified only 3 species, as introduced, and 4 cryptic species, separated into 1 diatom, 5 dinoflagellates and 1 raphidophycean (Lopes et al., 2009). However, phytoplankton constitute a set of organisms that are difficult to identify. This fact points to the use of the polyphasic identification technique, represented by the use of a series of morphological and molecular characteristics, as a more powerful method for making decisions in ballast water monitoring programs (Lopes et al., 2009).

Ojaveer et al. (2018) have already asserted that the advancement and application of new molecular and genomic methods will continue broadening our view of past invasions. However, a lack of quantitative high-resolution analyses and detection methods directed to marine bio invaders and their histories results in a further deepening about the effect of the baseline change syndrome. This implies a lack of more complete understanding and recognition of the full extent of the problem. Manso and Tenente (1984) state that one of the advantages of molecular biology is that this technique is not subject to typical variations as the action of the environment, the developmental stage of the organisms, and other factors that could alter their morphology, therefore, molecular tools can avoid incorrect classification. To reduce the gap of the classic taxonomy and separate new records from possible bio invasions, this work aims to identify the species present in the ballast water and to compare these species with the ones present in the region of influence of two important ports in the south of Brazil.

\section{MATERIAL AND METHODS}

\section{Areas of study}

The collection of samples of ballast water come from vessels of the merchant fleet berthing in the port complex of Itajaí and Navegantes, Santa Catarina, both located in the lower estuary of the Itajaí River (latitude $27^{\circ} 35^{\prime} 48^{\prime \prime} \mathrm{S}$ and longitude $048^{\circ} 32^{\prime} 57^{\prime \prime} \mathrm{W}$ ), in the south of Brazil (Figure 1). The maximum size of vessels that can operate in the port complex is 306 meters in length. A vessel of this size is capable to generate more than $700,000 \mathrm{~m}^{3}$ of ballast water per year, according to Caron Jr. (2007).

\section{Sampling and species identification by microscopy}

The local phytoplankton samples for genetic comparison with the samples obtained from the ballast water of the ships come from the port complex on Figure 1. The purpose was to confirm whether the organisms of the different collection fields were members of the same species. The objective was to confirm whether the organisms belong to the same species.

To achieve this goal, it was necessary to perform vertical sampling in the water column every month, from July 2015 to January 2016, using a 2 m hosepipe. Sample collection also occurred from the use of a cylindrical-conical plankton net with an opening of $30 \mathrm{~cm}$ in diameter and mesh size of $20 \mu \mathrm{m}$.

It was possible to obtan a total of 7 ballast water samples (Table I) and 8 samples from the port complex environment. The samples collected were stored in sterile amber glass bottles and refrigerated, for use in the cultures. The ballast water was sampled by inserting 
a submersible 500 gpm Rule ${ }^{\circledR}$ pump, coupled to an electrical cable, which was connected to a $12 \mathrm{v}, 45 \mathrm{~A}$ automotive battery, through the main hold of the ballast tank. For the collection of phytoplankton, a filtering cup with a $20 \mu \mathrm{m}$ opening was connected to the outflow of the pump. The pump was activated for 3 minutes, pumping an average filtered volume of 72 liters. After this period, the material collected in the cup was transferred to sterilized amber bottles, and refrigerated. Part of the collected material was fixed in $4 \%$ formaldehyde in a laboratory, and analyzed in an inverted microscope (Olympus, model IX51) with phase contrast and magnification from $100 \times$ to $400 \times$ for the taxonomic identification with Utermohl method. The identification was performed through analysis of morphometric characteristics to the lowest taxon as possible, based on the studies of Cupp (1943), Ricard (1987), Balech (1988), Fukuyo et al. (1990), Round, Crowford and Mann (1990), Tomas (1997), Hasle and Syvertsen (1997), Faust and Gulledge (2002), Fryxell and Hasle (2003), Tenenbaum et al. (2004), Sant'Anna et al. (2006), Bicudo and Menezes (2006).

Figure 1 - Port complex of the towns Itajaí (the upper portion) and Navegantes (the lower portion), Santa Catarina state, south of Brazil

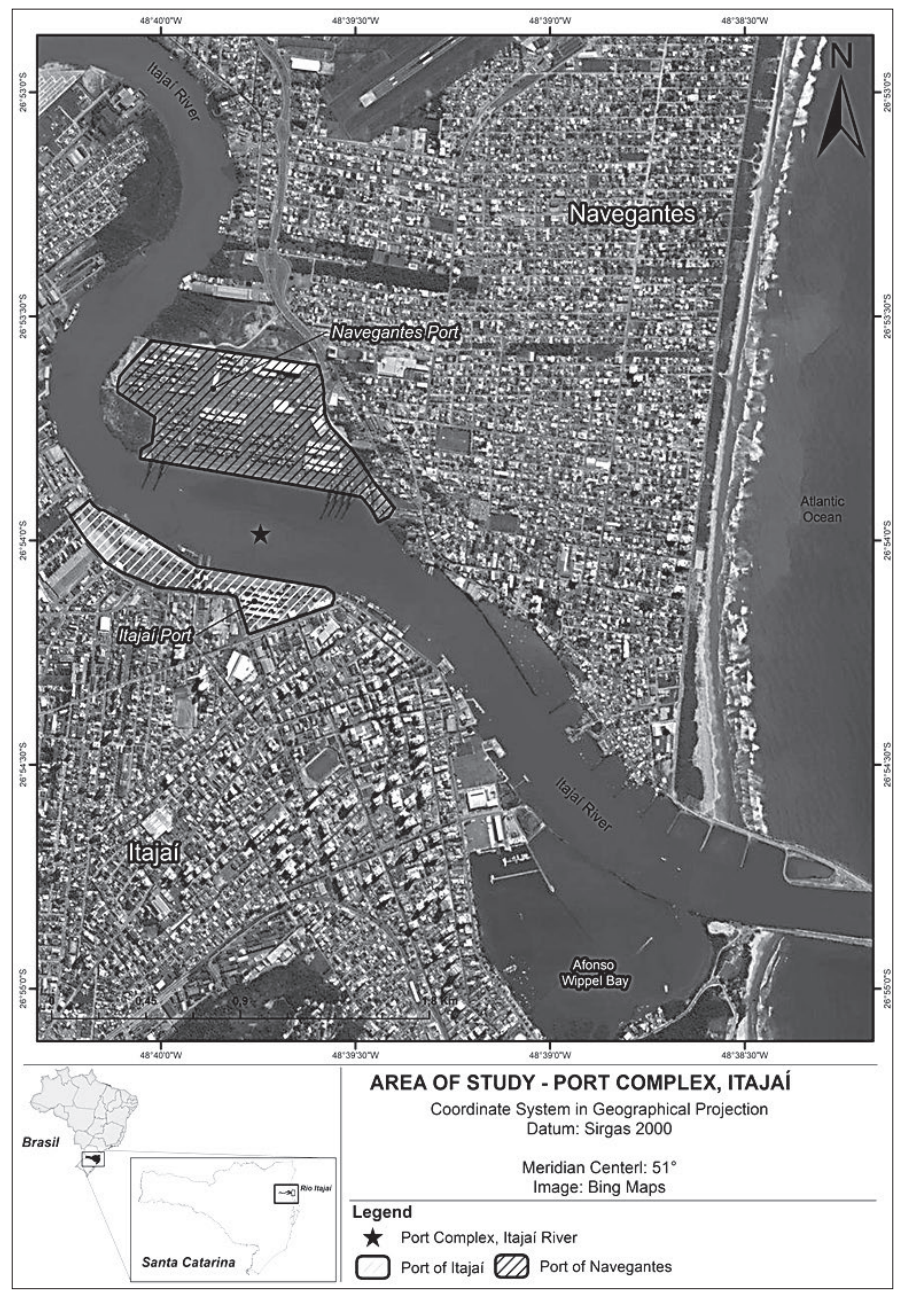

\section{Culture techniques}

For the cultures, the media f/2 (Guillard, 1975) and K medium (Keller \& Guillard, 1985) were used, following the original salinity of the sample. The illumination used was 
90- $\mu \mathrm{mol} \mathrm{s}{ }^{-1} \mathrm{~m}^{-2}$, with a photoperiod of 12 hours light/dark and an average temperature of $23.0^{\circ} \mathrm{C} \pm 0.5^{\circ} \mathrm{C}$. All species were cultivated and maintained in a laboratory using the clonal system, from a single cell obtained by the micropipetting technique and successive dilution (Andersen, 2005). When each culture reached the exponential growth phase, and as the most axenic form possible, part of it was centrifuged for concentration of the biomass produced, resulting in a precipitate that was immediately frozen and sent for molecular identification. To evaluate the growth performance of the cultured species, growth curves were built for 9 species: 2 Chlorophyceae ( 1 from ballast water and 1 from the local environment), and 7 Diatom ( 3 from ballast water and 4 from the environment). All of these were incubated for a maximum of 9 days, peak of the exponential growth phase curve. The species T. mobiliensis was the only one that did not evolve from a lag phase. The other species showed the development of a lag phase followed by a rapid (exponential) growth phase, with a stationary phase and a senescence phase as the nutrients were depleted.

\section{BioMol analysis}

The conduction of molecular analyses took place in the Marine Algae Laboratory (Laboratorio de Algas Marinhas - LAM) of the Instituto de Biociências (IB) of the Universidade de São Paulo (USP). DNA extraction of the microalgae was performed using a NucleoSpin ${ }^{\circledR}$ Plant $I$ kit, following the manufacturer's protocols, with an initial sample amount of 70-120 $\mu \mathrm{L}$. The rDNA complete ITS region, which has between a 50 to $600 \mathrm{pb}$ (White et al., 1990), was amplified using the primers 1853 'F (Forward) and $2855^{\prime} \mathrm{R}$ (Reverse) respectively, by the polymerase chain reaction (PCR) technique. The success of the extraction and amplification of the DNA was verified by electrophoresis in $0.7 \%$ agarose gel in TAE buffer (Tris-acetate $40 \mathrm{mM}$; EDTA $2 \mathrm{mM}$ ), using a 1Kb marker (DNA Ladder-Invitrogen). To determine the sizes of the amplified fragments, they were stained with GelRed at a concentration of 1:500, under UV light, in order to determine the integrity and quality of the sample.

Observing the success in the amplification of the DNA, the products of the PCR, fragments of the genes ITS were purified using a GFX Illustra kit (GE). For the reaction of sequencing, an aliquot of the PCR product was added to the reagent of the BigDye Terminator Cycle Sequencing Ready Reaction kit (Applied Biosystems), and submitted to the sequencing cycle in a thermocycler (Techne TC-4000 and TC-512). They were subsequently submitted to the process of DNA precipitation and resuspension in formamide and sequenced (3130xl Applied Biosynthesis or 3730DNA Life Technologies). Primers of the SSU (Ribosomal Small Subunit) rDNA region of the complete ITS1 and ITS2 and the 5.8S gene (region 18S3'F, 28S5' R, 5.8SF and 5.8SR were used).

These sequences were subsequently processed using the bioinformatics Software and manually cleaned. This unique sequence was researched in the NCBI GenBank (Highly similar sequences - megablast) database, through the BLAST study. The sequences were processed in consensus of the forward and reverse sequences obtained, which are complementary. Each result considered optimum was compared with those deposited in the gene bank to obtain the species identification. The $\mathrm{Q}$ values (PHRED) were used to evaluate the quality of the chromatogram. For the definition of operational taxonomic units, a limit of $97 \%$ was adopted to demonstrate specific similarity. For the samples that did not present amplification, some parameters were adjusted for a better response, such as the annealing temperature gradients, increase in magnesium concentration, change in extension time, addition of tween, new pairs of primers, and another extraction kit, with 
various combinations of these variables. In the end, the decision was to separate the portions analyzed into pairs of primers, $18 \mathrm{~S} 3^{\prime} \mathrm{F}$ with $5.8 \mathrm{R}$ and $5.8 \mathrm{~F}$ with $28 \mathrm{~S} 55^{\prime} \mathrm{R}$.

As a result of the genetic sequencing, confirmation of the species was initially performed by the Identity (Ident) criteria followed by the Query cover, and in the case of any remaining doubts, the scores and global alignments were compared, observing whether the divergences were nucleotide substitutions or gaps.

\section{RESULTS}

It was possible to obtain a total of 7 ballast water samples (Table I) and 8 samples from the port complex environment. In the port environment, the salinity ranged from 0.4 to 32.2 (tidal variation in the estuary) while the ballast water samples presented variations on the same scale of magnitude, i.e. between 1.4 and 36.4 (salinity of water at the collection site), indicating controversies in relation to the IMO guideline, which provides for the alteration of ballast water in oceanic regions. This fact led to the recording of freshwater and marine, planktonic, benthic and surf zone species (Table II).

Table I - Date of collection, salinity value and port of origin for ballast water collected in the hulls of ships berthing at the ports of Itajaí and Navegantes. NI = Not Informed. \#numbers are only sample control

\begin{tabular}{ccccc}
\hline Sample & Collection & Ballast & Salinity & Origin \\
\hline Navegantes \#18 & $9 / 14 / 2015$ & $8 / 15 / 2015$ & 1.4 & Manaus \\
Navegantes \#22 & $11 / 23 / 2015$ & $11 / 21 / 2015$ & 30.6 & NI \\
Navegantes \#23 & $11 / 27 / 2015$ & $11 / 20 / 2015$ & 34.3 & Oceanic \\
Navegantes \#1 & $1 / 22 / 2016$ & $6 / 18 / 2015$ & 30.4 & Oceanic/Atlantic Ocean \\
Itajaí \#1 & $1 / 30 / 2016$ & $1 / 18 / 2015$ & 35.4 & Oceanic/Atlantic Ocean \\
Navegantes \#3 & $2 / 16 / 2016$ & $1 / 22 / 2016$ & 36.4 & Coastal/Gulf of Mexico \\
Itajaí \#2 & $2 / 25 / 2016$ & $2 / 12 / 2016$ & NI & Manaus \\
\hline
\end{tabular}

Table II - Successfully cultured species and their respective habitats

\begin{tabular}{ccc}
\hline Species & Environment & Origin \\
\hline Asterionellopsis glacialis & Coast/Surf zone & Ballast \\
Cylindrotheca closterium & Marine & Ballast \\
Desmodesmus sp. & Freshwater & Port Complex \\
Ditylum brightwellii & Marine & Port Complex \\
Neodesmus sp./Closterium sp. & Freshwater & Ballast \\
Pectinodesmus holtmannii & Freshwater & Ballast \\
Pleurosigma sp. & Marine & Port Complex \\
Pseudo-nitzschia spp. & Marine & Port Complex \\
Pseudopediastrum boryanum & Freshwater & Ballast \\
Pseudopediastrum boryanum & Freshwater & Port Complex \\
Skeletonema pseudocostatum & Coastal/Estuarine & Port Complex \\
Skeletonema sp. & Coastal/Estuarine & Port Complex \\
Thalassionema nitzschioides & Marine & Port Complex \\
Thalassiosira cf. rotula & Marine & Ballast \\
\hline
\end{tabular}


(continuation Table I)

\begin{tabular}{ccc}
\hline Species & Environment & Origin \\
\hline Thalassiosira minima & Marine & Port Complex \\
Thalassiosira minima & Marine & Port Complex \\
Thalassiosira minuscula & Marine & Ballast \\
Thalassiosira minuscula & Marine & Ballast \\
Thalassiosira minuscula & Marine & Ballast \\
Thalassiosira minuscula & Marine & Ballast \\
Thalassiosira sp.1 & Marine & Port Complex \\
Trieres mobiliensis & Marine & Port Complex \\
\hline
\end{tabular}

For the cultures, it was possible to obtain 10 strains from ballast water and 12 strains from the environment around the port complex. Some species occurred in more than one sample and were isolated into separate times, for example Thalassiosira minima from the natural environment and T. minuscula from the ballast environment. Only Skeletonema spp. and Thalassiosira spp. occurred in both environments during the studied period. Both genera hardly distinguished the identification and the level of species under microscopy, so it was decided to group them as genus and not as species. Of the total ballast water samples (Table I), 3 (42.9\%) did not have live organisms at the time of collection and did not present organisms with growth.

As shown in Figure 2, the majority of the species studied presented their maximum growth at between 6 and 8 days of cultivation, with a decrease on day 9. Chlorophyceae was the algae with the highest growth rates, attaining density of more than $2 \times 10^{8}$ cell/L, e.g. Pectinodesmus holtmannii, while the maximum number reached by the diatom was less than $1 \times 10^{8}$ cell/L, e.g. Asterionellopsis glacialis.

Figure 2 - Growth curves (median for the triplicates) of the species obtained in the port complex (PC) and ballast (B) water samples. The secondary axis was used for species $P$. holtmannii and P. boryanum for the large number of cells/L

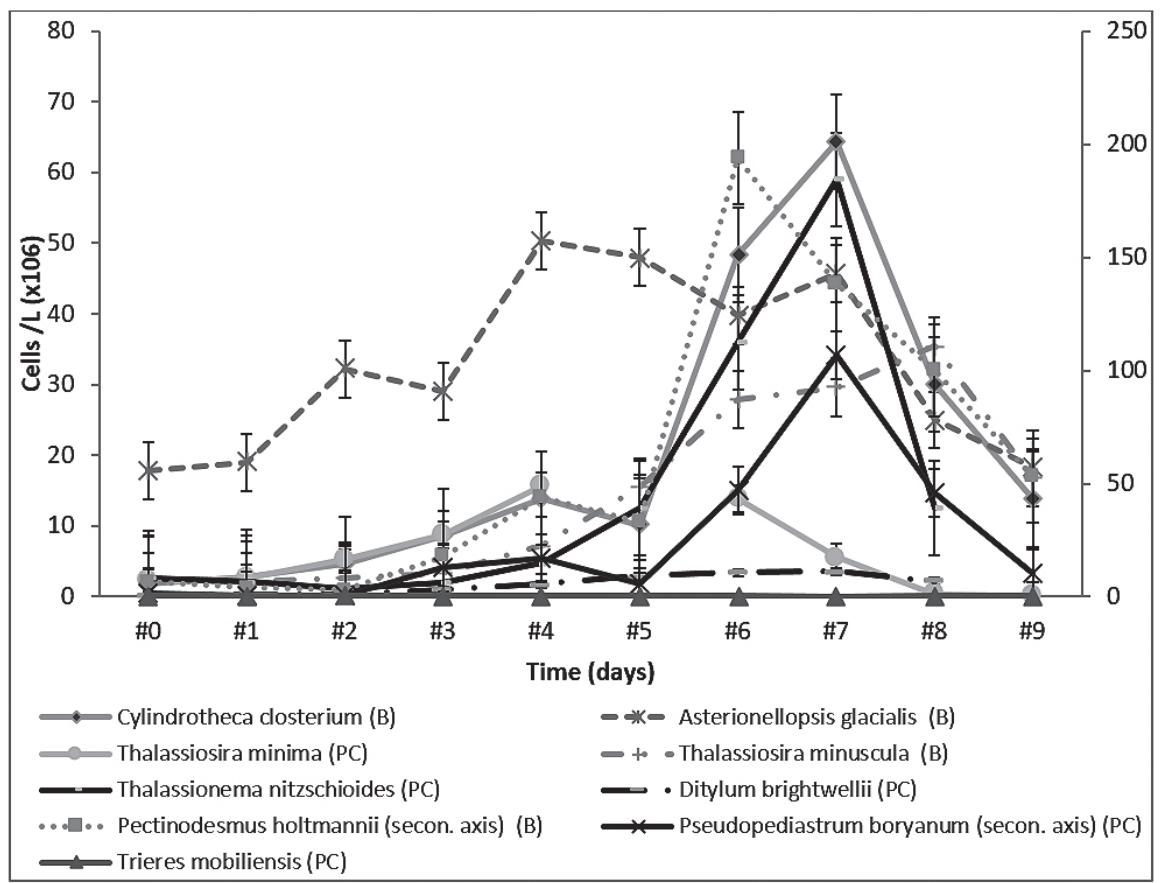


Table III shows the species confirmed through the molecular identification, and their possible divergences from microscopic identification. Of the 22 cultures performed successfully, ballast water plus natural environment, 17 species were successfully sequenced. For those in which there was amplification, it was possible to obtain some weakened bands, but the majority of them presented intense and unique bands. Table III shows the successfully analyzed portions for each species.

Table III - Comparison between microscope and molecular identification of species collected from ambient (PC) and ballast (B) waters in the port complex of Itajaí and Navegantes (south of Brazil). Number of base pairs (Bp). \#numbers are only sample control

\begin{tabular}{|c|c|c|c|c|c|}
\hline & Origin & Taxonomic ID & Molecular ID & Bp & Primer \\
\hline$\# 1$ & PC & Desmodesmus sp. & - & - & - \\
\hline \#3 & PC & Skeletonema sp. & Skeletonema pseudocostatum & 560 & 18SF \\
\hline$\# 4$ & PC & Skeletonema sp. & - & 270 & $5.8 \mathrm{~F}$ \\
\hline$\# 7$ & PC & Thalassiosira sp.1 & Thalassiosira minima & 688 & $28 \mathrm{SR}+28 \mathrm{SRb}+18 \mathrm{SF}+5.8 \mathrm{~F}$ \\
\hline \#8 & PC & Pleurosigma sp. & Pleurosigma sp. & 570 & $18 \mathrm{SF}+28 \mathrm{SR}+5.8 \mathrm{~F}$ \\
\hline$\# 9$ & PC & Ditylum brightwellii & - & - & - \\
\hline$\# 10$ & PC & Pseudo-nitzschia sp. & - & 670 & $18 \mathrm{SF}+18 \mathrm{SFb}+28 \mathrm{SR}+28 \mathrm{SRb}$ \\
\hline$\# 13$ & PC & Thalassionema nitzschioides & - & - & - \\
\hline \#15 & PC & Thalassiosira cf. rotula & Thalassiosira minima & 690 & $18 \mathrm{SF}+28 \mathrm{SR}+5.8 \mathrm{~F}$ \\
\hline \#18 & PC & Trieres mobiliensis & Trieres mobiliensis & 310 & 28SR \\
\hline \#19 & PC & Thalassiosira sp.1 & - & 630 & $18 S F+28 S R$ \\
\hline \#22 & PC & Pediastrum duplex & Pseudopediastrum boryanum & & $18 \mathrm{SF}+28 \mathrm{SR}+5.8 \mathrm{~F}$ \\
\hline \#2 & B & Thalassiosira sp. & Thalassiosira minuscula & 650 & $18 \mathrm{SF}+28 \mathrm{SR}$ \\
\hline \#5 & B & Thalassiosira sp.1 & Thalassiosira minuscula & 650 & $18 \mathrm{SF}+5.8 \mathrm{R}+5.8 \mathrm{~F}$ \\
\hline \#6 & B & Thalassiosira sp. & Thalassiosira minuscula & 713 & $18 \mathrm{SF}+28 \mathrm{SR}+5.8 \mathrm{~F}$ \\
\hline \#11 & B & Scenedesmus sp. & Pectinodesmus holtmannii & 657 & $18 \mathrm{SF}+28 \mathrm{SR}+5.8 \mathrm{~F}$ \\
\hline \#12 & B & Pediastrum duplex & - & 450 & $18 \mathrm{SF}+28 \mathrm{SR}+5.8 \mathrm{~F}$ \\
\hline \#14 & B & Thalassiosira sp. 2 & Thalassiosira minuscula & 657 & $28 \mathrm{Srb}+18 \mathrm{SF}+18 \mathrm{SF}$ \\
\hline \#16 & B & Asterionellopsis glacialis & Asterionellopsis glacialis & & $18 \mathrm{SF}+18 \mathrm{SFb}+28 \mathrm{SR}+28 \mathrm{SRb}+5.8 \mathrm{Fb}$ \\
\hline \#17 & B & Cylindrotheca closterium & - & 440 & $5.8 \mathrm{~F}$ \\
\hline \#20 & B & Thalassiosira cf. rotula & - & 630 & $18 \mathrm{SF}+18 \mathrm{SFb}+28 \mathrm{SR}+28 \mathrm{SRb}+5.8 \mathrm{Fb}$ \\
\hline \#21 & B & Closterium sp. & Neodesmus sp. & & $18 \mathrm{SF}+18 \mathrm{SFb}+28 \mathrm{SR}+28 \mathrm{SRb}+5.8 \mathrm{Fb}$ \\
\hline
\end{tabular}

Only the species Pleurosigma elongatum W. Smith, Skeletonema pseudocostatum, Thalassiosira minscula, Thalassiosira minima, Asterionellopsis glacialis, Neodesmus sp., Pseudopediastrum boryanum, described in Table IV, were confirmed by BLAST.

Table IV - Result of BLAST studies comparing the sequences studied

\begin{tabular}{|c|c|c|c|c|c|}
\hline Description & $\begin{array}{c}\text { Max } \\
\text { score }\end{array}$ & $\begin{array}{l}\text { Total } \\
\text { score }\end{array}$ & $\begin{array}{l}\text { Query } \\
\text { cover }\end{array}$ & E value & Ident \\
\hline Pleurosigma elongatum isolate TFPV2 358 internal transcribed spacer & 237 & 237 & $27 \%$ & $3 \mathrm{E}-58$ & $93 \%$ \\
\hline Skeletonema pseudocostatum clone M2 internal transcribed spacer 1 & 965 & 965 & $97 \%$ & 0.0 & $99 \%$ \\
\hline Skeletonema pseudocostatum clone M2 internal transcribed spacer 1 & 549 & 549 & $100 \%$ & $1 \mathrm{E}-153$ & $99 \%$ \\
\hline Thalassiosira minuscula strain COMP 1093 18S ribosolam RNA & 924 & 924 & $100 \%$ & 0.0 & $97 \%$ \\
\hline Thalassiosira minima genomic DNA containing $18 \mathrm{~S}$ rRNA gene, ITS1, 5.8S & 1251 & 1251 & $100 \%$ & 0.0 & $99 \%$ \\
\hline Asterionellopsis glacialis collected-by P. Hargraves $18 \mathrm{~S}$ & 758 & 758 & $99 \%$ & 0.0 & $100 \%$ \\
\hline Neodesmus sp. UTEX 2219-4 internal transcribed spacer1, partial sequence & 630 & 630 & $88 \%$ & 8E-177 & $94 \%$ \\
\hline Pseudopediastrum boryanum strain KMMCC 1331 18S ribosomal RNA & 1072 & 1072 & 100 & 0.0 & $100 \%$ \\
\hline
\end{tabular}




\section{DISCUSSION}

The different habitats that exist in Santa Catarina coast, characterized particularly by a broad range of physical/chemical parameters (e.g. salinity and temperature) (Stramosk, 2014), may favor the colonization of different organisms coming from the ballast water. The salinities observed in the ballast water obtained in this work suggest, in addition to the increasing risk, that ships were not changing their ballast content in deep-sea regions, as recommended by the IMO to reduce the risk of bioinvasion. Also, the results show an inefficiency to use any other methods to improve the quality of the water when discharging or if it was done so, it was not effective, as out of a total of 7 samples obtained from ballast water $4(57.1 \%)$ presented viable species for cultivation.

The microalgae studied showed growth performance between days 6 and 8 of cultivation, with a decrease on day 9. It is possible to estimate that this may be the period of development of the growth cycle and start of the senescence phase. In addition, the minimum retention time of the ballast could reduce the risk of bioinvasion, as pointed out by Gollasch et al. (2007). Specifically in relation to diatom, the results demonstrated their high capacity for survival after confinement in ballast tanks. Diatoms showed a more pronounced development than others did, with high acclimation and potential for establishment in local ambient. This kind of result corroborates for Hyun et al. (2017) and Klein et al. (2010), who affirmed the high survival capacity of that group in confined environments. This result may be related to the presence of frustules (Cupp, 1943) which give cell protection, resistance and robustness to the systems of cultivation and manipulation. A good example of this protection is shown by the species Ditylum brightwellii (T. West) Grunow, 1885, and the genus Pleurosigma due to their broader frustule who described high growth. Despite this, some cultures develop up to a certain point, but in a few days, and for unidentified reasons, the entire culture entered the senescence phase, as occurred with the species Rhizosolenia setigera (Brightwell, 1858), Dactyliosolen fragilissimus (Bergon) Hasle, 1996, Aulacoseira granulata (Ehrenberg) Simonsen, 1979, Closterium spp. (Brébisson, 1856), Prorocentrum micans (Ehrenberg, 1834), and Chaetoceros spp. (Ehrenberg, 1844).

Considering that phytoplankton are photoautotrophs, the amount of time they remain in the ballast water and the environment from which they are collected might have been crucial factors for the transfer of species such as from the genus Pleurosigma. This is considered as belonging to the benthic environment; the species Asterionellopsis glacialis which is characteristic of the surf zone; and the freshwater genera Aulacoseira, Pediastrum, Scenedesmus, which cannot withstand high salinity. The occurrence of these species in the samples and growth-curve assays may support the suspicion that the coastal ballast water had not been changed in deep-sea regions. On the other hand, if the port of destination presents similar environmental conditions, the risk will be increased for the local phytoplankton community structure and dynamics. The ecological success of species that are capable of growing in a ballast environment, considered very inhospitable for photosynthetic organisms because it is a dark environment, characterizing a pre-selection feature for a potential invasive species. This fact demonstrates the role of ships as important vectors for the dispersion of species around the globe, particularly more adaptable species, increasing the chances of establishment and ecological success of new species in environments where they were previously not found. 
It is possible to interpret the impacts of exotic species as causing a decline in ecological quality due to changes in the biological, chemical and physical properties of aquatic ecosystems (Elliott, 2003).

The species Thalassiosira minuscula is considered harmful, not because it produces toxins, but because of its great capacity for mucilage production and its rapid growth. This mucilage obstructs the gills of the fish causing high mortality from hypoxia (Hallegraeff; Anderson \& Cembella, 2003). The chances of this species establishing itself in the environment of the port complex of Itajaí and Navegantes are great and already proven by this work, since it was possible to cultivate the species with the environmental characteristics of the waters of the port region. This was one of the only species successfully cultivated and sequenced in two environments: ballast and port complex of Itajaí and Navegantes. With the ITS region it was possible to indicate that two species are the same, but it was not possible to assess whether they belong to the same lineage.

Another species that deserves attention is Asterionellopsis glacialis, as it has been proven that it can survive very well in inhospitable and dark environments such as basements for ballast water, an introduction of organisms with these characteristics would be possibly catastrophic and, also, the competition for nutrient would be unfair, negatively impacting the entire local community.

\section{Molecular identification}

This work identified the following strains, subdivided between marine and freshwater species:

\section{Marine species}

Pleurosigma sp.: it was not possible to confirm the full identity of this cultured species. Despite the existence of 266 species and infraspecies, only eight have molecular identification in the GenBank. Four of these eight identifications are at genus level. Likewise, it was not possible to confirm the species through the classic taxonomy, as the diacritical characters were not evident in the optical microscopy. The organism found in this study has no genetic description. This indicates that this study represents an addition to the description of the species of this genus. For further studies, the authors would describe thoroughly the morphological features by scanning electron microscopy and transmission electron microscopy.

Round, Crawford and Mann (1990) placed it in the Family Naviculaceae and described it as being of single cells. They have convex valves, sigmoids and striae with resolution in points (Smith, 1852). They are characteristically epipelic in sand or mud but in rare cases, it occurs in the marine plankton. It is a genus with benthic characteristic, indicating that the ballast water where it was found may have been collected in an estuary of low depth, where the hydrodynamic processes favor the resuspension of the sediment on the seabed (Antaq, 2016). This fact corroborates the theory presented by Caron Jr. (2007) and Stramosk (2014) that ships harboring at the port complex had not changed their ballast water in deep-sea, posing a possible bioinvasion, or in this case, biointroduction.

Another exacerbating factor that magnifies the risk of undesired biointroduction is the presence of sediment in the bottom of the tanks, as this can provide theideal environment for the development of species of epibenthic species, independent of their origin (Hallegraeff \& Bolch, 1992; Hallegraeff, 1998; Gollasch et al., 2007; Cruz, 2013). This type of substrate 
facilitates survival during the voyages, particularly for those that form cysts of resistance (Hallegraeff, 1998).

Skeletonema sp.: it has always been used as synonymous for $S$. costatum, being a misidentification. The genetic sequencing of the ITS region indicated that the culture of Skeletonema sp. should be the species S. pseudocostatum. Two separate strains were cultured, both collected from the environment around the ports of Itajaí and Navegantes. The identification of practically all Skeletonema species was performed under an optical microscope, being almost impossible to identify the species precisely. Sarno et al. (2005) described Skeletonema as being easy to cultivate and widely tolerant, particularly to salinity, flourishing in nutrient-rich coastal waters around the world. Medlin et al. (1991) were the first to recognize a new species, $S$. pseudocostatum, using a polyphasic approach. The scant knowledge of $S$. pseudocostatum might be related to its relatively recent description and the description amended by Sarno et al. (2005).

Thalassiosira spp.: there were identified two strains at species level, the first confirmed as Thalassiosira minuscula (from ballast water and the port complex environment) and the second as Thalassiosira minima (from port complex environment only). Nonetheless, Thalassiosira may vary considerably during their life cycle (Figure 3), not only in size, but also in their geometry and valve morphology (e.g. starting cells). Often, only the larger vegetative valves (auxospores) can be identified unequivocally (Hoppenrath et al., 2007), making it difficult to understand the ecological roles of this group.

Figure 3 - Auxospore of Thalassiosira sp. in culture

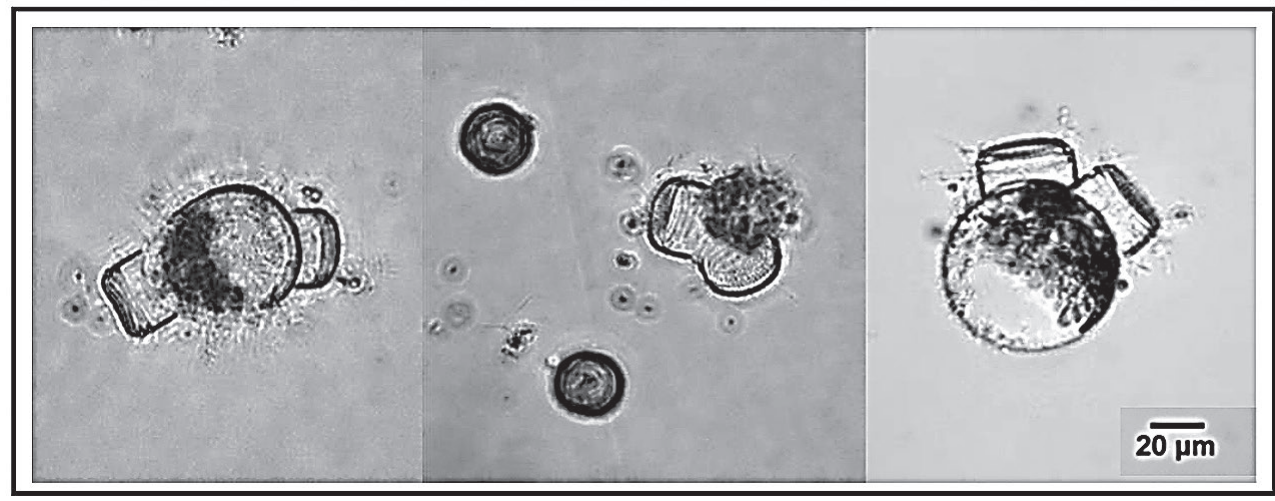

Thalassiosira minuscula: according to a survey carried out by Garcia and Odebrecht (2009), T. minuscula should be synonymous with T. monoporocyclus (Hasle, 1972) and recorded in the Atlantic and Pacific oceans, close to Portugal and Peru, occurring in a broad interval of temperature and salinity. In the present study, the species T. minuscula was found in salinity of 31 in ballast water and 32.2 in the region of the port complex in the summer and autumn seasons. It was not possible to identify precisely under optical microscopy due to their small size. Furthermore, checklists of species that do not address a polyphasic approach have been considered disputable.

That species is considered harmful, not because it produces toxins, but due to its high capacity to produce mucilage and its rapid growth. This mucilage can clog the gills of fish, causing high mortality by hypoxia (Hallegraeff; Anderson $\mathcal{E}$ Cembella, 2003). As demonstrated in this work, the chances of this species becoming established in the port complex of Itajaí and Navegantes are high, considering it was possible to perform the culture under similar 
environmental conditions simulated at lab. It was successfully cultured and sequenced from both types of environments: ballast water and port complex of Itajaí and Navegantes, SC. With the ITS region it was possible to affirm that both species are the same, but it was not possible to evaluate whether they belong to the same strain.

Thalassiosira minima: as classified as cosmopolitan species, it is commonly found in brackish and marine, temperate waters (Hoppenrath et al., 2007), and is tolerant to broad ranges and variations in temperature and salinity (Muylaert \& Sabbe, 1996; McQuoid, 2005). Its identification is considered equally difficult. It presented the same growth performance as T. minuscula and might have the same advantages in the process of bioinvasion and establishment in new harbor environments.

Asterionellopsis glacialis: it was unobserved a lag phase, with this species having a high tolerance to the plasticity of the culture medium. It was possible to note high production of mucilage in the senescence phase, where the cells were clustered by an organic amorphous system. Studies (Kaczmarska et al., 2014; Körner, 1970; Du Preez \& Campbell, 1996; Tomas, 1997) indicated that this species can grow in a broad thermal range: from $-1^{\circ} \mathrm{C}$ to $23^{\circ} \mathrm{C}$ in nature and up to $30^{\circ} \mathrm{C}$ in vitro (Kaczmarska et al., 2014) and in a wide range of salinities (Körner, 1970; Du Preez \& Campbell, 1996; Tomas, 1997). According to Villac and Kaczmarska (2011), they can survive for days in the absence of light, buried in sediments of ballast tanks on ships.

Cylindrotheca closterium: it was possible to affirm through the classic taxonomy that this is the species Cylindrotheca closterium, because the morphological and diacritical characteristics are different for the structures of the species typically found in the study region. However, based on the analysis of the genetic ITS1 and ITS2 regions, it was not possible to confirm by comparison. Although the use of regulated molecules is not possible, no indication of $N$. longissima was indicated, corroborating our identification in optical microscopy. Therefore, further studies are recommended with other discriminatory genetic regions, as this is another, undescribed species or a subspecies of C. closterium. According to the listing of the Integrated Taxonomic Information System (ITIS), there are currently three species described: C. closterium, C. fusiformis and C. gracilis. As in the gene bank GenBank, the number of works that describe this genus is low and there are only two studies deposited in the gene bank (identified as KY693718 and KY323509) with description of the species that are related to the sample studied.

\section{Freshwater species}

Pectinodesmus holtmannii: the BLAST search resulted in a chromatogram considered clean, without secondary peaks or noise, generating no doubt for the identification of the specimens/samples. Hegewald, Bock and Krienitz (2013) described this species as belonging to continental waters.

Neodesmus danubialis: it was observed that the molecular identification that most resembled it, from the culture performed with ballast water samples, was Neodesmus sp., based on one of three studies performed with this genus (Hegewald \& Hanagata, 2000; Wang et al., 2011; Baytut et al., 2013). However, the BLAST study showed only a $94 \%$ 
identity with $88 \%$ coverage. As the identification is not confirmed, there is strong evidence that Neodesmus sp. may be the same as Neodesmus danubialis.

Pseudopediastrum boryanum: in the present study, the genera Pediastrum and Pseudopediastrum were confused. This was probably because of their masked diacritical characters, which according to Komárek and Fott (1983), were: morphology of the processes and projections, ornamentation of the wall, and morphology of the marginal cells. These characteristics were not visible under light microscopy. Seeta, Navatha and Manikya (2016) and Pasztalenies and Poniewozik (2004) indicated that there would be 24 known species of the genus Pseudopediastrum, but only four have truly global distribution (P. boryanum, $P$. duplex (Meyen, 1829), P. tetras (Ehrenberg, 1845) and P. simplex (Meyen, 1829). They are commonly found in freshwater bodies, particularly surface water that is rich in organic matter (Lenarczyk, 2015). The culture initially identified as Pediastrum duplex grew successfully, coming both from ballast water and from the region around the port complex. However, its genetic sequencing in the ITS1 and ITS2 regions showed that the correct identification must have to be Pseudopediastrum boryanum. The morphological plasticity resulting from the monospecific culture generated doubts to its correct identification. Pseudopediastrum boryanum is considered highly polymorphic, especially in terms of the number and arrangement of cells in the cenobium. Also, P. boryanum may be confused with P. angulosum (Ehrenberg ex Meneghini, 1840), P. integrum (Nägeli, 1849) and P. duplex (Restano, 2013). In general, the culture of strains of phytoplankton did not prove to be the best method for molecular identification, as the culturable fraction represented only a small portion of the whole phytoplanktonic community present. Of this culturable fraction, an even smaller fraction was correctly sequenced. Additional analyses should use complementary methods, such as other primers, other extraction kits, and the analysis of different gene regions, in order to identify the origin/strain of the species. The metagenomic technique is the most interesting, but it is costly to perform.

\section{Ecological implications}

Algal blooms strongly impact coastal areas around the world as they are capable of producing significant biomass. It is even possible to find potentially toxic species and, in this case, the regional economy can be strongly impacted.

One of the sectors that may be impacted, for example, are mariculture, considered the most important activity in the coastal area of the state of Santa Catarina, a region very close to the area in which this study was developed. According to data published by Epagri $(2016,2017)$ there was a $12.36 \%$ reduction compared to 2016 , due to harmful algal blooms, an event formerly known as red tide.

Streftaris, Zenetos and Papathanassiou (2005) listed 53 non-native phytoplankton species between the Arctic, Baltic, North Atlantic, Mediterranean and Black seas. These species are divided between 25 dinoflagellates and 15 diatoms. De Castro, Fileman and Hall-Spencer (2017) described that there are reports of 44 species associated with high impacts for the NE Atlantic and 15 for the SW Atlantic, although this may be an underestimate. In Brazil, in the last list made available by the Ministry of the Environment, researchers identified only three species as introduced and four cryptic species, divided between one Bacillariophyta, five Dinoflagellata and one Raphidophyta (Lopes et al., 2009). This discrepancy between the work carried out abroad and the data found in Brazil in 
relation to bioinvasion, provides an erroneous notion regarding environmental risk. The low number found in the country is due to the scarcity of works carried out in this area and not to the low risk. Soler-Figueroa et al. (2020) conducted several tests in 32 ports on the American coast and proved that the natural populations of phytoplankton are poorly resolved. None of the ports met land-based challenge conditions, and only $32 \%$ met requirements for shipboard testing. Approximately $71 \%$ of organisms $\geq 50 \mu \mathrm{m}$ were centric diatoms, also unregulated by current protocols that consider smaller size than $<50 \mu \mathrm{m}$. This study demonstrates that current regulations do not consider natural phytoplankton populations, limiting control efforts for potentially harmful non-indigenous species.

\section{Molecular biology $\mathrm{x}$ classical taxonomy}

Molecular biology techniques are efficient, but with greater technical and financial demand, with a slightly longer response time compared to classical identification techniques in optical microscopy. The latter may raise doubts about the correct identification of species, but many are extremely practical for a large volume of samples and are efficient if they have the support of an experienced taxonomist.

The use of identification techniques that can assist in monitoring programs, such as the polyphasic technique, becomes important, since it is based on the identification of organisms based on morphological and molecular diversity (Lopes et al., 2009). It is a new approach in monitoring ballast water for the Brazilian coast.

The cultivation of phytoplankton strains did not prove to be the best method for molecular identification, since the cultivable fraction represented only a tiny part of the entire phytoplankton community present. From this small cultivable fraction, an even smaller fraction was sequenced correctly. As an additional analysis, the use of complementary methods should be used, such as the use of other primers, other extraction kits and analysis of different gene regions, in order to identify the origin/ lineage of the species. The metagenomic technique would be the most interesting, but of the highest cost.

\section{CONCLUSIONS}

Based on the information presented on this, it was observed that the salinity range of the ballast water samples was broad, providing good conditions for the presence of freshwater species from the genera Pectinodesmus, Pseudopediastrum and Neodesmus, benthic species such as Pleurosigma sp. and the surf zone one Asterionellopsis glacialis. This fact confirms the suspicion that ballast water had not been changed in deep-sea regions and the methods used are not being efficient considering the observation of sweet and viable species for crops. A polyphasic view in the identification of species shown to be important, as taxonomy under optical microscopy is not shown sufficient in the identification of several specimens at the species level, being maintained at maximum taxonomic levels. A molecular biology with the ITS1, ITS2 and 5.8S region proved to be quite efficient in the identification of organisms at the species level. Molecular biology with the ITS1, ITS2 and $5.8 \mathrm{~S}$ regions, meanwhile, proved highly efficient in the identification of the species and the correct taxonomy, resolving doubts in the identification. The growth capacity of phytoplankton isolates from ballast water in culture conditions has been proven. In this regard, it is possible to affirm the possibility of being transported, with high chances of 
establishment in the (similar) environment of the destination port. In particular, diatom presented greater adaptation and ease of growth, suggesting higher resistance to adverse conditions in the ballast water environment.

Acknowledgements - We acknowledge the Presidential of Republic of Brazil - CapesProsup system the for the scholarship; dra. Mariana Cabral de Oliveira of the Laboratório de Algas Marinhas of the USP for the opportunity to perform the genetic analysis; and our colleague Cesar Augusto Stramosk for collecting all the samples analyzed in this research.

\section{BIBLIOGRAPHIC REFERENCES}

Andersen, R.A. Algal culturing technique. San Diego: Elsevier, 578 p., 2005.

Antaq. Agência Nacional de Transportes Aquaviários. Ministério do Meio Ambiente. Uso de água de lastro. Available in: http://web.antaq.gov.br/portalv3/MeioAmbiente_AguaDeLastro. asp. Accessed in: 12 March 2016.

Balech, E. Los dinoflagelados del Atlántico Sudoccidental. Publ. Espec. Inst. Español Oceanogr., 310 p., Madrid, 1988.

Baytut, Ö.; Gürkanli, C.T.; Özkoç, İ. \& Gönülol, A. Assessing $18 \mathrm{~S}$ rDNA diversity of the chlorophytes among various freshwaters of the Central Black Sea Region. Turkish Journal of Fisheries and Aquatic Sciences, v. 13, p. 811-818, 2013.

Bicudo, C.E.M. \& Menezes, M. Gênero de algas de águas continentais do Brasil (chave para identificação e descrição). São Carlos: RiMa Editora, 489 p., 2006.

Bolch, C.J. \& Salas, M. F. de. A review of the molecular evidence for ballast water introduction of the toxic dinoflagellates Gymnodinium catenatum and the Alexandrium "tamarensis complex" to Australasia. Harmful Algae, v. 6, n. 4, p. 465-485, 2007.

Caron Jr., A. Avaliação do risco de introdução de espécies exóticas no porto de Itajaí e entorno por meio de água de lastro. Dissertation, Environmental Science and Technology, Universidade do Vale do Itajaí, 138 p., Itajaí, 2007.

Castro, M.C.T. de; Fileman, T.W. \& Hall-Spencer, J.M. Invasive species in the Northeastern and Southwestern Atlantic Ocean: a review. Marine Pollution Bulletin, v. 116, n. 1-2, p. 4147, 2017.

Cruz, F.R. Zooplâncton da água de lastro do Porto de Itajaí. Dissertation, Center for Technological Sciences of Land and Sea, Universidade do Vale do Itajaí, 35 p., Itajaí, 2013.

Cupp, E.D. Marine plankton diatoms of the West of North America. Bulletin of the Scripps Institution of Oceanography, California, v. 6, 237 p., 1943.

Du Preez, D.R. \& Campbell, E.E. The photophysiology of surf diatoms: a review. Revista Chilena de Historia Natural, v. 69, p. 545-551, 1996.

Elliott, M. Biological pollutants and biological pollution: an increasing cause for concern. Marine Pollution Bulletin, v. 46, n. 3, p. 275-280, 2003.

Epagri. Maricultura. Sintese anual da agricultura em Santa Catarina 2016-2017. Florianópolis, 3 p., 2018. Available in: http://docweb.epagri.sc.gov.br/website_epagri/Cedap/Estatistica-Sintese/ Sintese-informativa-da-maricultura-2016.pdf. Accessed in: 20 Nov. 2019. 
Epagri. Síntese informativa da maricultura 2017. Florianópolis, 8 p., 2018. Available in: http:// docweb.epagri.sc.gov.br/website_epagri/Cedap/Estatistica-Sintese/Sintese-informativa-damaricultura-2017.pdf. Accessed in: 20 Nov. 2019.

Faust, M.A. \& Gulledge, R.A. Identifying harmful marine dinoflagellates. US Natl. Herb., v. 42, p. 1-144, 2002.

Fryxell, G.A. \& Hasle, G.R. Marine diatoms, p. 1-44, in Hallegraeff, G.M.; Anderson, D.M. \& Cembella, D.M. Manual on harmful marine microalgae. Intergovernmental Oceanographic Commission/UNESCO, 793 p., Paris, 2003.

Fukuyo, Y.; Takano, H.; Chihara, M. \& Matsuoka, K. Red-tide organisms in Japan - an illustrated taxonomic guide. Tokyo: Uchida Rokakucho, 1990.

Garcia, M.A. \& Odebrecht, C. Morphology and ecology of Thalassiosira Cleve (Bacillariophyta) species rarely recorded in Brazilian coastal waters. Revista Brasileiria de Biologia, v. 69, n. 4, p. 1059-1071, 2009.

Gollasch, S.; David, M.; Voigt, M.; Dragsund, E.; Hewitt, C. \& Fukuyo, Y. Critical review of the IMO international convention on the management of ships' ballast water and sediments. Harmful Algae, v. 6, n. 4, p. 585-600, 2007.

Guillard, R.R. Culture of phytoplankton for feeding marine invertebrates, in Culture of marine invertebrate animals. Boston, MA: Springer, p. 29-60, 1975.

Hallegraeff, G.M. \& Bolch, C.J. Transport of toxic dinoflagellate cysts via ship' ballast water. Mar. Pollut. Bull., v. 22, p. 27-30, 1992.

Hallegraeff, G.M. Transport of toxic dinoflagellates via ships' ballast water: bioeconomic risk assessment and efficacy of possible ballast water management strategies. Marine Ecology Progress Series, v. 168, p. 297-309, 1998.

Hallegraeff, G.M.; Anderson D.M. \& Cembella, A.D. (ed.). Manual on Harmful Marine Algae. Unesco, 794 p., 2003.

Hasle, G.R. Thalassiosira subtilis (Bacillariophyceae) and two allied species. Norwegian Journal of Botany, v. 19, n. 2, p. 111-137, 1972.

Hasle, G.R. \& Syvertsen, E.E. Marine diatoms, p. 5-385, in Identifying marine phytoplankton, Academic Press, 858 p., 1997.

Hegewald, E.; Bock, C. \& Krienitz, L. A phylogenetic study on Scenedesmaceae with the description of a new species of Pectinodesmus and the new genera Verrucodesmus and Chodatodesmus (Chlorophyta, Chlorophyceae). Fottea, v. 14, n. 2, p. 149-164, 2013.

Hegewald, E. \&Hanagata, N. Phylogeneticstudies onScenedesmaceae(Chlorophyta). Archiv für Hydrobiologie, v. 136, p. 29-49, 2000.

Hoppenrath, M.; Beszteri, B.; Drebes, G.; Halliger, H.; Van Beusekom, J.E.E.; Silvia, J. \& Wiltshire, K.H. Thalassiosira species (Bacillariophyceae, Thalassiosirales) in the North Sea at Helgoland (German Bight) and Sylt (North Frisian Wadden Sea). European Journal of Phycology, v. 42, n. 3, p. 271-288, 2007.

Hyun, B.; Baek, S.H.; Shin, K. \& Choi, K.H. Assessment of phytoplankton invasion risks in the ballast water of international ships in different growth conditions. Aquatic Ecosystem Health \& Management, v. 20 (4), p. 423-434, 2017. 
Kaczmarska, I.; Mather, L.; Luddington, I.A.; Muise, F. \& Ehrman, J.M. Cryptic diversity in a cosmopolitan diatom known as Asterionellopsis glacialis (Fragilariaceae): implications for ecology, biogeography, and taxonomy. American Journal of Botany, v. 101, n. 2, p. 267286, 2014.

Keller, M.D. \& Guillard, R.R.L. Factors significance to marine dinoflagellates culture, p.113-116, in Anderson, D.M.; White, A. \& Baden, D.G. (ed.). Toxic dinoflagellates. New York: Elsevier, xxx p., 1985.

Klein, G.; Mcintosh, K.; Kaczmarska, I. \& Ehrman, J.M. Diatom survivorship in ballast water during trans-Pacific crossings. Biol. Invasions, v. 12, p. 1031-1044, 2010.

Komárek, J. \& Fott, B. Chlorophyceae (Grünalgen), Ordnung: Chlorococcales, p. 824-940, in HuberPestalozzi, G. (ed.). Das Phytoplankton des Süßwassers. E Schweizerbart'sche Verlagsbuchhandlung, Nägele u. Obermiller, xxx p., Stuttgart, 1983.

Körner, H. Morphologie und taxonomie der diatomeengattung Asterionella. Nova Hedwigia, v. 20, p. 557-724, 1970.

Lenarczyk, J. The Algal Genus Pediastrum Meyen (Chlorophyta) in Poland. Institute of Botany PAS, Kraków. Acta Botanica Hungarica, v. 57, n. 3-4, p. 446-447, 2015.

Lopes, R.M.; Coradin, L.; Pombo, V.B. \& Cunha, D.R. Informe sobre as espécies exóticas invasoras marinhas no Brasil/Ministério do Meio Ambiente. Brasília: MMA/SBF, 440 p., 2009.

Manso, S.B.G. \& Tenente, R.C.V. Nematóides (Heterodera glycines Ichinohe) formador do cisto da soja. Brasília: Embrapa, v. xx, n. xx, 5 p., 1984.

McQuoid, M.R. Influence of salinity on seasonal germination of resting stages and composition of microplankton on the Swedish west coast. Marine Ecology Progress Series, 289, p. 151-163, 2005.

Medlin, L.K.; Elwood, H.J.; Stickel, S. \& Sogin, M.L. Morphological and genetic variation within the diatom Skeletonema costatum (Bacillariophyta): evidence for a new species, Skeletonema pseudocostatum. Journal of Phycology, v. 27, n. 4, p. 514-524, 1991.

Muylaert, K. \& Sabbe, K. The diatom genus Thalassiosira (Bacillariophyta) in the Estuaries of the Schelde (Belgium/The Netherlands) and the Elbe (Germany). Bot. Mar., v. 39, p.103116, 1996.

Neves, F.M \& Barbosa, L.C.B.G. Homogeneização da biodiversidade global: o caso das espécies invasoras, p. 1-20, in Encontro Associação Nacional de Pós-graduação e Pesquisa em Ambiente e Sociedade, Florianópolis, 20 p., 2010.

Ojaveer, H.; Galil, B.S.; Carlton, J.T.; Alleway, H.; Goulletquer, P. \& Lehtiniemi, M. Historical baselines in marine bioinvasions: implications for policy and management. PLoS ONE, v. 13, n. 8, 2018. Available in: https://journals.plos.org/plosone/article?id=10.1371/journal. pone.0202383. Accessed in: 8 Oct. 2018.

Pasztaleniec, A. \& Poniewozik, M. Pediastrum Species (Hidrodictyaceae, Sphaeropleales) in Phytoplanckton os Sumin Lake. Acta Societatis Botanicorum Poloniae, v. 73, n. 1, p. 39-46, 2004.

Restano, A.M. Família Hydrodictyaceae (Sphaeropleales, Chlorophyceae) no estado de São Paulo: levantamento florístico. Dissertation, Instituto de Botânica da Secretaria do Meio Ambiente do Estado de São Paulo, 164 p., São Paulo, 2013. 
Ricard, M. Atlas du phytoplancton marin: diatomophycées. Centre National de la Recherche Scientifique, Paris, v. 2, 297 p., 1987.

Round, F.E.; Crawford, R.M. \& Mann, D.G. Diatoms: biology and morphology of the genera, Cambridge: University Press, 775 p., 1990.

Sant'Anna, C.L.; Azevedo M.T.P.; Agujaro, L.F.; Carvalho, M.C.; Carvalho, L.R. \& Souza, R.C.R. Manual ilustrado para identificação e contagem de cianobactérias planctônicas de águas continentais brasileiras. Interciência, Rio de Janeiro, v. 1, 58 p., 2006.

Sarno, D.; Kooistra, W.H.C.F.; Medlin, L.K.; Percopo, I. \& Zingone, A. Diversity in the genus Skeletonema (Bacillariophyceae): an assessment of the taxonomy of S. costatum - like species, with the description of four new species. Journal of Phycology, v. 41, p. 151-176, 2005.

Seeta, Y.; Navatha, K. \& Manikya, P.R. Distribution of Pediastrum in Dal lake, Kashmir, India. J. Algal Biomass Utln., v. 7, n. 1, p. 56-61, 2016.

Smith, W. Notes on the diatom with descriptions of british species included in the genus Pleurosigma. Natural History, v. 2, n. 9, p. 1-12, 1852.

Souza, R.C.C.L. Água de lastro: uma ameaça à biodiversidade. Reunião Anual da Sociedade Brasileira para o Progresso da Ciência. 62a . Anais... Natal, RN, 2010.

Soler-Figueroa, B.M.; Fontaine, D.N.; Carney, K.J.; Ruiz, G.M. \& Tamburri, M.N. Characteristics of global port phytoplankton and implications for current ballast water regulations. Marine Pollution Bulletin, v. 155, 111165, 2020.

Stramosk, C.A. Ocorrência e viabilidade de espécies fitoplanctônicas em amostras de água de lastro de navios mercantes no porto de Itajaí - SC. Dissertation, Master in Vegetal Biology, Universidade Federal de Santa Catarina, 77 p., Florianópolis, 2014.

Streftaris, N.; Zenetos, A. \& Papathanassiou, E. Globalization in marine ecosystems: the story of non-indigenous marine species across European seas. Oceanogr. Mar. Biol.: Ann. Rev., v. 43, p. 419-453, 2005.

Tenenbaum, D.R.; Villac, M.C.; Viana, S.C.; Matos, M.; Hatherly, M.; Lima, I.V. \& Menezes, M. Phytoplankton atlas of Sepetiba Bay, Rio de Janeiro. London: IMO, p. 132. 2004.

Tomas, C.R. (ed.). Identifying marine phytoplankton. San Diego, California: Academic Press, 858 p., 1997.

Villac, M.C. \& Kaczmarska, I. Estimating propagule pressure and viability of diatoms detected in ballast tank sediments of ships arriving at Canadian ports. Marine Ecology Progress, v. 425, p. 47-61, 2011.

Wang, S.T.; Pan, Y.Y.; Liu, C.C.; Chuang, L.T. \& Chen, C.N. Effects of photosynthesis and osmotic stress on oil body formation. Bot. Stud., v. 52, p. 305-312, 2011.

White, T.J.; Bruns, T.; Lee, S. \& Taylor, J. Amplification and direct sequencing of fungal ribosomal RNA genes for phylogenetics, p. 315-322, in Innis, M.A.; Gelfand, D.H.; Sninsky, J.J. \& White, T.J. (ed.). PCR protocols: a guide to methods and applications, New York: Academic Press, p. 315-322, 1990.

Wittenberg, R. \& Cock, M.J.W. Invasive alien species: a toolkit of best prevention and management practices. CAB International, Wallingford, Oxon, UK, 228 p., 2001. 


\section{ANNEX 1}

Complementary material: list of species controlled in the environmental monitoring program for ballast water in the port complex of the towns Itajaí and Navegantes, Santa Catarina state, south of Brazil

\begin{tabular}{|c|}
\hline Bacillariophyta \\
\hline Mediophyceae \\
\hline Bacteriastrum delicatulum \\
\hline Bacteriastrum hyalinum \\
\hline Bacteriastrum sp. \\
\hline Bellerochea/Lauderia \\
\hline Bellerochea horologicales \\
\hline Biddulphia aurita \\
\hline Biddulphia sp. \\
\hline Biddulphia tuomeyi \\
\hline Campylosira cymbelliformis \\
\hline Cerataulina pelagica \\
\hline Chaetoceros aequatorialis \\
\hline Chaetoceros affinis \\
\hline Chaetoceros atlanticus \\
\hline Chaetoceros brevis \\
\hline Chaetoceros castracanei \\
\hline Chaetoceros coarctatus \\
\hline Chaetoceros compressus \\
\hline Chaetoceros curvisetus \\
\hline Chaetoceros danicus \\
\hline Chaetoceros decipiens \\
\hline Chaetoceros didymus \\
\hline Chaetoceros diversus \\
\hline Chaetoceros eibenii \\
\hline Chaetoceros gracilis \\
\hline Chaetoceros laciniosus \\
\hline Chaetoceros lorenzianus \\
\hline Chaetoceros peruvianus \\
\hline Chaetoceros radicans \\
\hline Chaetoceros socialis \\
\hline Chaetoceros subtilis \\
\hline Chaetoceros subtilis var. abnormis \\
\hline Chateoceros laevis \\
\hline Chateoceros sp.1 \\
\hline Chateoceros spp. \\
\hline Climacodium frauenfeldianum \\
\hline Cyclotella sp. \\
\hline Ditylum brightwellii \\
\hline Eucampia cornuta \\
\hline
\end{tabular}

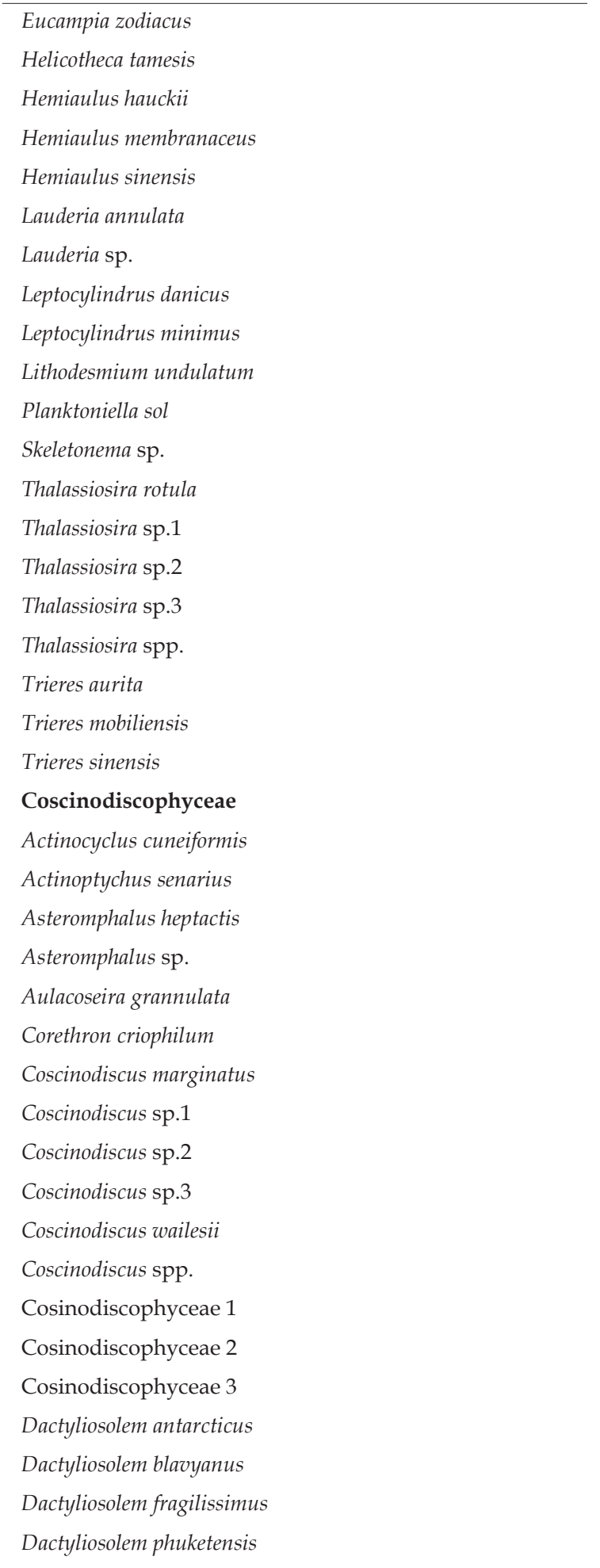




\section{Guinardia delicatula}

Guinardia flacida

Guinardia striata

Melosira moliniformis

Melosira varians

Melosira sp.

Neocalyptrella robusta

Paralia sulcata

Podosira stelligera

Proboscia alata

Pseudosolenia calvar-avis

Rhizosolenia alata

Rhizosolenia hyalina

Rhizosolenia imbricata

Rhizosolenia pungens

Rhizosolenia robusta

Rhizosolenia setigera

Rhizosolenia styliformis

Rhizosolenia sp.

\section{Fragilariophyceae}

Asterionellopsis glacialis

Fragilaria capucina

Fragilariaceae 1

Fragilariaceae 2

Fragilariaceae 3

Fragilariaceae 4

Fragilariopsis sp.

Grammatophora marina

Grammatophora sp.

Synedra/Fragillaria

Thalassionema cf. pseudonitzschioides

Thalassionema frauenfeldii

Thalassionema nitzschioides

Thalassionemataceae

\section{Bacillariophyceae}

Amphora sp.

Bacillaria paxillifer

Bacillariaceae 1

Bacillariaceae 2

Bacillariaceae 3

Bacillariaceae 4

Bacillariaceae 5

Bacillariaceae 6

Bacillariaceae 7

Cylindrotheca closterium

Diploneis crabro
Diploneis sp.1

Diploneis sp.2

Diploneis sp.3

Entomoneis alata

Gyrosigma sp.

Haslea wawrikae

Lioloma pacificum

Lyrella lyra

Mastogloia sp.

Meuniera membranacea

Navicula distans

Navicula sp.1

Navicula sp.2

Navicula sp.3

Navicula sp.4

Navicula sp.5

Navicula sp.6

Navicula sp.7

Naviculaceae 1

Naviculaceae 2

Nitzschia longissima

Nitzschia longissima var. reversa

Nitzschia reversa

Nitzschia sigma

Nitzschia sigmoidea

Nitzschia sp.

Pleurosigma acutum

Pleurosigma aestuarii

Pleurosigma elongatum

Pleurosigma normanii

Pleurosigma sp.1

Pseudo-nitzschia

Pseudo-nitzschia "complexo delicatissima"

Pseudo-nitzschia "complexo seriata"

Pseudo-nitzschia multistriata

Surirella fastuosa

\section{Dinoflagellata}

\section{Dinophyceae}

Amphisolenia bidentata

Alexandrium cf. fraterculus

Amphisolenia sp.

Dinophysis acuminata

Dinophysis caudata

Dinophysis fortii

Dinophysis tripos 
Gonyaulax sp.

Gymnodiniales

Gymnodinium sp.

Gyrodinium sp.

Gyrodinium spirale

Karenia sp.

Ornithocercus magnificus

Oxyphysis oxytoxoides

Oxytoxum scolopax

Oxyphysis sp.

Peridinium sp.

Podolampas palmipes

Podolampas spinifera

Polykrikos sp.

Protoperidinium bipes

Protoperidinium divergens

Protoperidinium excentricum

Protoperidinium oviforme

Protoperidinium pentagonum

Protoperidinium sp.

Protoperidinium steinii

Protoperidinium venustum

Pyrocystis lunula

Pyrocystis sp.

Scrippsiella sp.

Scrippsiella trochoidea

Torodinium teredo

Tripos azoricus

Tripos brevis

Tripos candelabrum

Tripos declinatum

Tripos declinatum $\mathrm{f}$. normale

Tripos furca

Tripos fusus

Tripos hircus

Tripos horriudum

Tripos cf. incisum

Tripos cf. karsteni

Tripos kofoidii

Tripos lunula

Tripos macroceros

Tripos massiliense

Tripos pentagonum

Tripos symmetrium

Tripos teres

Tripos trichoceros
Tripos tripos
Tripos sp.
Tryblionella compressa
Tryblionella gracile
Tryblionella micans
Tryblionella minimum
Tryblionella obtusum
Tryblionella rhathymum
Tryblionella rostratum
Tryblionella scutellum
Tryblionella sigmoides
Tryblionella sp.
Tryblionella triestinum
Tryblionellamexicanum

Noctilucophyceae

Noctiluca scintillans

Noctiluca sp.

\section{Cyanophyceae}

Cylindrospermopsis sp.

Johannesbaptistia sp.

Oscilatoriaceae 1

Phormidiaceae - aff. Phormidium

Pseudanabaenaceae 1

Richelia intracellularis

Trichodesmium erythraeum

Cianofícea filamentosa

\section{Chlorophyta}

Acanthosphaera zachariasi

Actinastrum sp.

Closterium gracile

Closterium sp.

Coelastrum sp.

Crucigenia sp.

Desmodesmus acuminatus

Desmodesmus armatus

Desmodesmus protuberans

Desmodesmus sp.

Golenkinia sp.

Micractinium pusillum

Monoraphidium arcuatum

Pediastrum duplex

Scenedesmus acuminatus

Scenedesmus sp.1

Senedesmus sp.2 


\section{Cryptophyceae}

Hillea cf. fusiformis

Cryptophyceae

\section{Euglenophyceae}

Euglena acus

Euglena sp.

Phacus sp.

Phacus tortus

Strombomonas sp.

Trachelomonas sp.

\section{Coccolithophyceae}

Rhabdosphaera claviger

\section{Zygnematophyceae}

Staurastrum sp.

Staurodesmus sp.

\section{Silicoflagelados}

Dictyocha fibula

Ebria tripartita

Hermesinum adriaticum

Octactis octonaria

\section{Cistos}

Ciliado 